\title{
ע MS-tautiin sairastuneen toimijuus sosiaali- ja terveyspalveluissa
}

Hoito- ja kuntoutuskäytännöt ovat tärkeä osa muuttuvia sosiaali- ja terveyspalveluja. Artikkelin tarkoitus on tuoda esiin nuorena MS-tautiin sairastuneen oma näkökulma hänen kohtaamiinsa hoito- ja kuntoutuskäytäntöihin, jotta niitä voitaisiin kehittää. Aineistona on 14 työssä käyvän, 26-33-vuotiaan MS-tautiin sairastuneen haastattelua. Aineisto on analysoitu teoriaohjaavalla sisällönanalyysilla, jossa päättelyä on ohjannut Giddensin rakenteistumisteoria ja Jyrkämän teoreettismetodologinen viitekehys toimijuuden modaliteeteista. Tutkimus kohdistuu sosiaali- ja terveyspalvelujen toimintakäytäntöihin ja MS-tautiin sairastuneiden toimijuuteen suhteessa omaan sairauteen ja kuntoutukseen. Aineiston perusteella toimintakäytäntöinä toteutuva vuorovaikutus ammattilaisten kanssa ja omaan sairauteen suhtautuminen ohjasivat MS-tautiin sairastuneiden toimijuutta sosiaali- ja terveyspalveluissa. Tieto sairaudesta oli vaikea ottaa vastaan. Ensitiedon antamisen tapa sekä ammattilaisten toimintakäytäntöjä ohjaava tieto olivat yhteydessä haastateltujen mahdollisuuksiin hyväksyä oma sairautensa ja hakeutua kuntoutukseen. Ammattilaisten tuen puute ensitiedon yhteydessä jätti haastatellut yksin käsittelemään sairaustietoa ja ohjasi haastateltujen toimijuutta sairauden kieltäväksi ja torjuvaksi, itseään sairaudelta suojelevaksi tai sairauden suhteen odottavaksi. Jotta haastateltujen toimijuus sosiaalija terveyspalveluissa saattoi olla valtansa tiedostavaa ja omaa etua ajavaa, haastateltujen täytyi käsitellä sairauden vaikutusta elämään kokonaisvaltaisesti ja tiedostaa oma toimijuutensa sosiaali- ja terveyspalvelujen vuorovaikutuksessa. Tutkimuksen johtopäätöksinä todetaan, että haastateltujen vähäinen osallistuminen toimintakäytäntöinä toteutuvaan vuorovaikutukseen sosiaalija terveyspalveluissa vaikeutti aktiivisen ja oman sairauden hyväksyvän toimijuuden muodostamista. Kuntoutukseen hakeutumista saattoivat vaikeuttaa suomalaisen kuntoutusjärjestelmän monimutkaisuus ja puutteet kuntoutuksen suunnittelussa. Haastatellut olisivat voineet hyötyä psykologisesta varhaiskuntoutuksesta. Pitkäaikaissairaiden hoitokäytäntöjen käsitteellistäminen ja mallintaminen on keino kehittää kuntoutukseen ohjaamista ja kuntoutuksen sisältöjä sekä auttaa sairastunutta sairauden hyväksymisprosessissa.

\section{ASIASANAT: toimijuus, kuntoutus, MS-tauti, sosiaali- ja terveyspalvelut}

\section{SUVI-MAARIA TEPORA-NIEMI}

\section{JOHDANTO}

MS-tauti on nuorilla aikuisilla yleisin neuroimmunologinen sairaus, jota sairastaa noin 7000 suomalaista. Se ilmenee tavallisesti 20-40 vuoden iässä, naisilla yleisemmin kuin miehillä. (1)
MS-tauti on hajapesäkkeinen, eli tulehduspesäkkeitä ja hermokudoksen muutoksia ja toimintahäiriöitä syntyy eri puolille keskushermostoa. Tästä johtuen taudin oireet ovat moninaisia ja vaihtelevia. Tavallisimpia oireita ovat väsymys eli fa- 
tiikki, lihasheikkous, raajojen jäykkyys eli spastisuus, koordinaatiohäiriöt, ataksia, virtsarakon tyhjentämisvaikeus, virtsan karkailu, näköhäiriöt, puhe- ja nielemisvaikeudet, kognitiiviset häiriöt, kivut ja mielialaoireet. (2)

Taudin eteneminen on yksilöllistä ja vaikeasti ennustettavaa. Tauti etenee sairauden alussa 85 prosentilla sairastuneista aaltomaisesti muutaman viikon pituisina pahenemisvaiheina ja niitä seuraavina suvantovaiheina. Tilanne korjaantuu osin tai täysin suvantovaiheiden aikana. Vuosien kuluessa oireet usein muuttuvat vaikeammiksi. Noin 15 prosentilla sairastuneista sairaus etenee alusta alkaen tasaisesti eli progressiivisesti, ja suurimmalla osalla aaltomaisesti etenevä sairaus muuttuu 10-15 vuoden aikana tasaisesti eteneväksi. (2)

MS-tautiin sairastuneen sosiaali- ja terveyspalvelujen asiakkuuteen kuuluu kuntoutus. Koska MS-tauti on etenevä ja invalidisoiva, usein työkyvyttömyyteen johtava sairaus, on kuntoutus pitkällä aikavälillä välttämätöntä $(1,2)$. Kuntoutusta järjestetään julkisessa terveydenhuollossa sekä Kansaneläkelaitoksen ja työeläkekassojen kustantamana. Kuntoutukseen kuuluu lakisääteisesti kuntoutussuunnitelma, joka tulisi laatia mahdollisimman pian diagnoosin saamisen jälkeen sairastuneen ja moniammatillisen tiimin yhteistyönä. Kuntoutussuunnitelma on välttämätön Kelan ja terveydenhuollon kuntoutukseen ja terapioihin. Ilman suunnitelmaa kuntoutus jää yksittäisiksi toisistaan irrallisiksi toimenpiteiksi ja kuntoutuksen tavoitteellisuus ja seuranta epäselväksi (3).

MS-tautiin sairastuminen on nuorelle aikuiselle elämänmuutos, jolloin hän joutuu kohtaamaan itseään ja ympäristöään uudella tavalla. Sairauden diagnosointi on tärkeää ja välttämätöntä, mutta elämänmuutos ei rajaudu siihen. Tarkastelen artikkelissani sairastumisen tuomaa elämänmuutosta toimijuuden käsitteellä, koska sen avulla voidaan keskittyä yksilön mahdollisuuksiin ja voimavaroihin. Tutkimuksen kohteena oleva toimija on MS-tautiin sairastunut kuntoutuja, jonka näen kuntoutuksen valtaistavan paradigman mukaisesti ympäristö- ja vuorovaikutussuhteissaan (4). Sosiaali- ja terveyspalvelut ovat tila, jossa MS-tautiin sairastunut saa tiedon sairaudestaan ja alkaa muodostaa toimijuuttaan toimintakäytänteinä toteutuvassa vuorovaikutuksessa. Tutkimus kohdistuu haastatel- tujen toimijuuteen suhteessa omaan sairauteen ja kuntoutukseen.

Artikkeli liittyy keskusteluun sairauden ja toimijuuden suhteesta, johon ovat osallistuneet muun muassa sydän- ja verisuonisairauksia kulttuurin näkökulmasta tutkinut Honkasalo (5), pitkäaikaissairaiden toimijuutta Giddensin teorian avulla tutkinut Greener (6), potiluutta sairaalaosaston käytännöissä tutkinut Lämsä (7), muistisairaiden omaisten toimijuutta tutkinut Koivula (8), sekä aivoverenkiertohäiriöihin sairastuneiden kuntoutuskokemuksia tutkinut Reunanen (9). MS-tautia sairastaneiden kokemuksia ovat tutkineet aikaisemmin muun muassa Hoppe (10) ja Thapar ym. (11). Tämän artikkelin antina on MS-tautia sairastavien toimijuuden ja kokemusten kuvaaminen Suomen sosiaali- ja terveyspalveluissa.

\section{TOIMIJUUDEN TEOREETTINEN VIITEKEHYS}

Nyky-yhteiskunnassa edellytetään aiempaa enemmän elämänhallintaa, vaihtoehtojen pohdintaa ja valintojen tekemistä (12). Yksilön toimijuus konkretisoituu valinnoissa, joissa hän sen hetkisessä elämäntilanteessa pyrkii mahdollisimman hyvään ratkaisuun. Nykysosiologian klassikon Giddensin (13) ajatuksissa toimijuuden lähtökohta on toimijan rationaalisuus ja kyky reflektoida. Sosiaali- ja terveyspalveluja ja kuntoutusta niiden osana voidaan giddensiläisittäin luonnehtia sosiaaliseksi järjestelmäksi tai rakenteeksi, joka muodostuu toimintakäytännöistä. Toimijuus sosiaali- ja terveyspalveluissa muodostuu toimintakäytäntöinä toteutuvassa vuorovaikutuksessa (14). Toimintakäytäntöinä rakenteet ohjaavat ja rajaavat eri toimijoiden mahdollisuuksia. Kuitenkin rakenteet mahdollistavat toimijuuden ja toiminta tapahtuu aina suhteessa rakenteeseen. (13)

Giddensin (13) ajatuksissa toiminnan lähtökohtana on tiedostettu tai tiedostamaton aikomus, joka konkretisoituu toimintana. Hän käyttää subjekteista termejä tekijä ja toimija. Tekijällä ei ole tietoista reflektiota omasta toiminnastaan, eikä hän tiedosta muutosvoimaansa, kun taas toimijana subjekti osaa sanoittaa ja reflektoida tietonsa ja tietää myös muutosvoimansa. (15) Muutosvoimaa tai valtaa ei kuitenkaan voi käsitellä irrallaan rakenteesta. Paitsi sosiaalisia toimintakäytäntöjä rakenteet ovat Giddensille sääntöjen ja resurssien rakenteistamia. Näin säännöt ja resurssit ohjaavat tekijöiden ja toimi- 
joiden arkea. Ilman resursseja eivät toimijuutensa tiedostavatkaan ammattilaiset tai asiakkaat voi käyttää valtaansa muutosvoimana. Giddens ajattelee säännöt kulttuurin sisäiseksi piileväksi, hiljaiseksi tiedoksi. Ne eivät ole valmiiksi annettuja, vaan sääntöjen tulkinnoista käydään jatkuvia taisteluja. (16-18)

Giddensin (19) mukaan vuorovaikutuksena toteutuviin toimintakäytäntöihin liittyy tieto. Se voi olla tiedostamatonta, mutta myös käytännön tietoisuutta tai ilmaisullista, diskursiivisen tason, tietoisuutta. Käytännön tietoisuudella tarkoitetaan itsestään selvää tietovarantoa, jonka avulla toimijat muodostavat toimintakäytäntöjä. Ilmaisullista tietoisuutta toimijat ilmaisevat käsitteellisellä tasolla ajatusten vaihdossa ja keskustelussa. Toimijoiden välinen käsitteellisen tason keskustelu edellyttää toimintakäytäntöjen, niiden muodostumisen ja seurausten tiedostamista. Taito käsitteellistää toimintakäytäntöjä on tiedostavalle toimijalle keino käyttää muutosvoimaansa.

Toimijan näkeminen modernin subjektin tavoin rationaalisena, autonomisena yksilönä, jolla on vapaa tahto ja tietoisuus, ei huomioi ihmiselämään kuuluvia traagisia tilanteita kuten vakavaa sairastumista (20). Samoin huomiotta jäävät toimijoiden menneisyys, sosioekonominen tausta ja henkilökohtainen elämäntilanne sairaustiedon hetkellä. Jyrkämä (21) on muodostanut elämänkulkuun pohjautuvan toimijuuden modaliteettien teoreettis-metodologisen viitekehyksen, joka huomioi toimijuuden kokonaisvaltaisuuden. Viitekehyksen avulla toimijuutta eritellään kokonaisvaltaisesti dynaamisena prosessina, jossa modaliteetit muuttuvat ja vaikuttavat toinen toisiinsa.

Jyrkämän (21) kuusi modaliteettia ovat kykeneminen, osaaminen, haluaminen, täytyminen, voiminen ja tunteminen. Kykenemisen modaliteetilla tarkoitetaan fyysisiä ja psyykkisiä kykyjä. Osaamisen modaliteetti kattaa laajasti tietoja ja taitoja sekä erilaisia pysyviä ominaisuuksia, joita ihminen on elämänsä aikana oppinut. Haluamisen modaliteetti liittyy motivaatioon, tahtomiseen, päämääriin ja tavoitteisiin. Täytymisen modaliteettiin liittyvät niin fyysiset kuin sosiaaliset normatiiviset ja moraaliset esteet, pakot ja rajoitukset. Voimisen modaliteetti kattaa mahdollisuudet, joita kulloinenkin tilanne ja sitä ohjaavat rakenteet ja tekijät avaavat. Tuntemisen modaliteetti puolestaan kuvaa ihmisen ominai- suutta arvioida, arvottaa, kokea ja liittää omia tunteitaan kohtaamiinsa asioihin.

Modaliteettien viitekehyksessä toimijuus on jatkuvassa muutoksessa. Se ei ole sama asia kuin aktiivisuus tai produktiivisuus, vaan toimijuus voi olla myös tilanteellista vastarintaa, tilanteeseen sopeutumista, toisin toimimista tai osallisuutta omassa elämässä. (21) Modaliteettien avulla toimijuutta tarkastellaan tilannesidonnaisesti kontekstissaan, joka on verrattavissa Giddensin (13) ajatukseen toimijuudesta sosiaalisissa toimintakäytänteissä. Toimijuus muodostuu kunakin hetkenä sosiaali- ja terveyspalveluissa, eikä ole pysyvää. Koska sosiaali- ja terveyspalvelut järjestelmänä muuttuvat, myös toimijuuden konteksti muuttuu. Modaliteettien viitekehyksessä toimijuus muodostuu vuorovaikutuksessa toisten toimijoiden kanssa. (21) Sosiaali- ja terveyspalvelujen asiakkaiden toimijuutta ohjaavat ammattilaisten lisäksi heidän sidoksensa perheeseen, ystäviin ja asioihin kuten työhön, opiskeluun, harrastuksiin ja päivittäisiin rutiineihin. (Vrt. (22).)

\section{TUTKIMUKSEN TARKOITUS JA TUTKIMUSKYSYMYKSET}

Tutkimukseni tarkoitus on tuoda esiin MS-tautiin sairastuneen nuoren aikuisen oma näkökulma hänen kohtaamiinsa hoito- ja kuntoutuskäytäntöihin, jotta niitä voitaisiin kehittää. Tutkimuskysymykset on muodostettu tutkimukseni teoreettiseen viitekehykseen perustuen. Artikkelin ensimmäisenä tutkimuskysymyksenä on se, miten haastatellut pääsevät osaksi sosiaali- ja terveyspalvelujen toimintakäytäntöinä toteutuvaa vuorovaikutusta. Toinen tutkimuskysymys on tarkastella, millainen toimijuus haastatelluille muodostuu suhteessa omaan sairauteensa ja kuntoutukseen.

\section{TUTKIMUSHAASTATTELUT JA TUTKIMUKSEN EETTISYYS}

Vuonna 2012 haastattelin Kuntoutussäätiön ja MS-liiton -projektissa MS-tautia sairastavien ammatillinen kuntoutuminen ja työssä jaksaminen 14 MS-tautiin sairastunutta henkilöä, joista kolme oli miehiä ja yksitoista naisia. He olivat haastatteluhetkellä iältään 26-33-vuotiaita, ja he olivat saaneet diagnoosin 19-29-vuotiaina. Diagnoosin saamisesta oli kulunut vuodesta yhteentoista vuotta ennen haastatteluja. Kaikki haastatellut olivat haastatteluhetkellä työelämässä. Heistä viidellä oli tuolloin akateeminen loppututkinto, kolmella ammattikorkeakoulututkinto, 
kolmella toisen asteen ammatillinen tutkinto ja kolmella yliopisto- tai ammattikorkeakouluopinnot meneillään.

Haastatellut valikoituivat vastaamalla MSliiton Avain-lehdessä julkaistuun hakuilmoitukseen tai MS-liiton jäsenistölleen lähettämään haastattelukutsuun. Haastattelin kaikki halukkaat enkä haastattelujen jälkeen rajannut kenenkään haastattelua tutkimusaineiston ulkopuolelle. Kaikki haastatellut olivat siis MS-liiton jäseniä, ja he olivat itse halunneet osallistua tutkimukseen. Kuntoutussäätiön eettinen toimikunta oli hyväksynyt projektin tutkimussuunnitelman, jonka osana haastattelut tein (23). Haastattelut olivat haastateltaville henkilökohtaisia ja herkkiä tilanteita, minkä takia ne etenivät haastateltavien omilla ehdoilla. Lisäksi sairausdiagnoosi oli monella haastatelluista tuore. Minulta haastattelijana haastattelutilanteet vaativat erityistä eettistä herkkyyttä. (24) Ennen haastatteluja kävin kunkin haastateltavan kanssa läpi tutkimushankkeen ja sitä seuraavan väitöskirjaprojektini tarkoituksen kuntoutuksen kehittämiseksi. Haastattelutilanteet oli suunniteltu haastateltavia kunnioittaviksi ja kiireettömiksi. (23).

Haastatteluja ohjasi elämänkulkuun perustuva teemahaastattelurunko, jonka aiheina olivat työelämä, sairaus, kuntoutus ja tulevaisuudensuunnitelmat. Teemat suunnittelin yhdessä projektin työ- ja ohjausryhmän kanssa (23). Haastattelut kestivät ajallisesti reilusta tunnista kolmeen tuntiin. Haastattelut äänitettiin ja litteroitiin sanasta sanaan. Litteroitua aineistoa kertyi 393 A4-arkkia. Litteraatio anonymisoitiin huolellisesti (25).

\section{TUTKIMUSANALYYSI JA TUTKIMUKSEN LUOTETTAVUUS}

Laadulliselle tutkimukselle luonteenomaisesti minulla ei ollut haastatteluvaiheessa lukkoon lyötyjä ennakko-olettamuksia tutkimuksen teoriasta ja tuloksista $(26,27)$. Koska haastatteluhetkestä on analyysin tekemiseen vuosia, etäisyys omaan aineistooni helpotti analyysin teossa (28). Aloitin analyysin aineistolähtöisesti lukemalla aineistoa lukuisia kertoja läpi, jolloin pyrin mahdollisimman induktiiviseen ajatteluun (23, 29). Tällöin luentaani ohjasi kysymys, millaista haastateltujen todellisuus on sairauden kanssa. Kysymys tarkentui sairauden hyväksymiseen, jota kaikki haastateltavat käsittelivät läpi haastattelujen. Jyrkämä (23) hyödyntää elämänkulkua käsitteel- listäessään toimijuutta. Tämän käsitteellisen tulokulman avulla liitin haastateltujen elämäkulun toimijuuden muodostumiseen (27) ja kirjoitin tutkimukselleni teoreettisen viitekehyksen. Sen mukaisesti muodostin tutkimuskysymykset toimijuudennäkökulmasta.Toimijuudentilaksihahmotin sosiaali- ja terveyspalvelut.

Teoreettinen viitekehys ohjasi päättelyni abduktiiviseksi ja analyysini teoriaohjaavaksi (28). Käytännössä luin aineistoa teorian avulla keskittyen haastateltujen osallistumiseen vuorovaikutuksena toteutuviin sosiaali- ja terveyspalvelujen toimintakäytäntöihin sekä etsin haastateltujen elämänkulusta tekijöitä, jotka ohjasivat heidän toimijuutensa muodostumista suhteessa omaan sairauteensa ja kuntoutukseen. Analyysin aikana kävin systemaattisesti läpi haastateltujen saaman ensitiedon, suhteen kuntoutukseen, ammatillisen ja sosiaalisen tuen, selviytymiskeinot ja suhteen omaan sairauteen. Taulukoin tiedot itselleni analyysin tueksi ja rajasin työ- ja perhe-elämää koskevat asiat tämän artikkelin ulkopuolelle. (27, 30) Systemaattisen taulukoinnin jälkeen luokittelin aineistosta neljä toimijuuden tyyppiä, joiden muodostamista ohjasi toimijuuden käsite ja kirjoittamani teoreettinen viitekehys (28). Analyysini aluksi kuvailen aineistoa toimijuuden teorian avulla. Lopuksi esitän toimijuuden tyypit. Esimerkki luokan muodostamisesta on taulukossa 1.

Haastateltavat eivät vapaaehtoisuutena vuoksi edusta MS-tautia sairastavia keskimäärin, vaan saattoivat olla keskimääräistä paremmin voivia ja aktiivisempia. Haastattelut valikoituvat aineistonkeruun menetelmäksi, koska halusin tutkia kuntoutuksen kehittämistä kokemusten perusteella. Aineistonkeruun menetelmäni saattoi kuitenkin rajata huonokuntoisimpia MS-tautiin sairastuneita tutkittavien ulkopuolelle, mikä on aineistoni heikkous. Haastatteluilla aineiston keruun välineenä saavutin MS-tautiin sairastuneiden henkilökohtaisia ajatuksia sairastumisesta ja asiakkuudesta sosiaali- ja terveyspalveluissa sekä yksilöiden näkökulmia kuntoutukseen hakeutumisesta tai sen esteistä. Haastattelijana pyrin kunnioittamaan haastateltavien kerrontaa ja välttämään sen ohjaamista (23), mutta haastattelu on aina osin haastateltavan ja haastattelijan vuorovaikutusta. (31) Haastatteluissa toistuvat samankaltaiset kokemukset, ja aineisto toistaa itseään. (26). 


\begin{tabular}{|c|c|c|c|}
\hline Suora lainaus tutkimusaineistosta & Pelkistetty ilmaus & Alaluokka & $\begin{array}{l}\text { Toimijuuden } \\
\text { teoreettisen } \\
\text { viitekehyksen avulla } \\
\text { muodostettu luokka }\end{array}$ \\
\hline $\begin{array}{l}\text { ”...Hakeuduin sinne } \\
\text { työterveyspsykologille...sitten } \\
\text { pääsin omaan kuntaan... olen } \\
\text { tyytyväinenkin siihen, että olen saanut } \\
\text { käydä siellä sekä psykologi että } \\
\text { mielenterveyshoitaja ...jos ihan Kelan } \\
\text { tukea hakis siihen psykoterapiaankin.... } \\
\text { sitten olen käynnyt sellaisella } \\
\text { kuntoutuskurssilla...” }\end{array}$ & $\begin{array}{l}\text { Hyväksyvä suhde } \\
\text { sairauteen }\end{array}$ & \multirow[t]{2}{*}{$\begin{array}{l}\text { Oman sairauden } \\
\text { hyväksyminen }\end{array}$} & \multirow{4}{*}{$\begin{array}{l}\text { Tiedostava, omista } \\
\text { eduista taisteleva } \\
\text { toimijuus }\end{array}$} \\
\hline $\begin{array}{l}\text { jotenkin se täytyy hyväksyä, et just ei } \\
\text { ole enää terve siis sillä tavalla täysin... } \\
\text { eikä kaikki itsestään selvää et varsinkin } \\
\text { silloin kun se, et jalat ei toiminu...” }\end{array}$ & $\begin{array}{l}\text { Hyväksyvä suhde } \\
\text { sairauteen }\end{array}$ & & \\
\hline $\begin{array}{l}\text { ”... vähättely ... asioista, joista } \\
\text { kysyis, ... ei oteta vakavasti ... } \\
\text { kuntoutussuunnitelma, joka } \\
\text { ilmeisesti lakisääteisesti kaikille pitäis } \\
\text { tehdä, olen saanut ... aika suoraan } \\
\text { sanottuna kuvan, et olen liian terve } \\
\text { sellaiseen suunnitelmaan ... jostain } \\
\text { kuntoutuksesta vois olla hyötyä et } \\
\text { ainakin kartottaa sitä ... se olis ... } \\
\text { ennalta ehkäisevää ... ellei oo tosi } \\
\text { pahasti ... niin sitä ennen ei tehdä } \\
\text { yhtään mitään ennakoivaa ...” }\end{array}$ & $\begin{array}{l}\text { Aktiivinen, omia } \\
\text { asioita ajava suhde } \\
\text { kuntoutukseen }\end{array}$ & \multirow[t]{2}{*}{$\begin{array}{l}\text { Aktiivinen, taisteleva } \\
\text { ja omia etuja ajava } \\
\text { toimijuus suhteessa } \\
\text { kuntoutukseen }\end{array}$} & \\
\hline $\begin{array}{l}\text { ”... haluan asian viedä loppuun ja } \\
\text { selvittää ... joku muu ... semmosessa } \\
\text { tilanteessa, et on masentunut tai... } \\
\text { voimat vähissä ... voi apu jäädä } \\
\text { hakemattakin ..." }\end{array}$ & $\begin{array}{l}\text { Aktiivinen, omia } \\
\text { asioita ajava suhde } \\
\text { kuntoutukseen }\end{array}$ & & \\
\hline
\end{tabular}

\section{ENSIASKELEET TOIMIJUUDELLE SOSIAALI- JA TERVEYSPALVELUISSA}

Haastateltujen toimijuus sosiaali- ja terveyspalveluissa ja sen toimintakäytännöissä alkoi muodostua, kun he hakeutuivat lääkäriin ja yrittivät selvittää MS-tautiin liittyvien oireidensa syytä ennen MS-diagnoosia. Sairauden oireet vaikuttivat haastateltujen kykenemisiin sekä tunteisiin ja edelleen pakottivat heitä toimimaan hämmentävän muutoksen selvittämiseksi. Samalla heidän toimijuutensa alkoi muodostua vuorovaikutuksessa ammattilaisten kanssa sosiaalisina toimintakäytäntöinä. Haastatellut ja heitä kohdanneet ammattilaiset osallistuivat toimintakäytäntöihin omilla resursseillaan ja kutakin toimintakäytäntöä koskevalla tiedolla. $(14,19,21)$

Kun tieto sairaudesta oli tuore, haastateltujen resurssit sairauden käsittelyyn olivat vähäiset ja heidän toimijuutensa mahdollisuuksia kaven- sivat tunteet ja tiedostamaton tieto. Heitä voi toimijoina giddensiläisittäin kutsua tekijöiksi (15). $\mathrm{He}$ haavoittuivat helposti vuorovaikutuksessa ammattilaisten kanssa ja tämän seurauksena jäivät helpommin toimintakäytäntöinä toteutuvan vuorovaikutuksen ulkopuolelle.

Haavoittumiselta suojeli ammattilaisten ilmaisullisen tason tietoisuus toimintakäytännöistä ja ymmärrys asiakkaan resurssien vähäisyydestä sairauden käsittelyyn diagnoosin jälkeen. Jos ammattilaisten toimintakäytännöt perustuivat tiedostamattomaan ja käytännön tietoisuuteen, asiakkaiden tunteille ei jäänyt tarpeeksi tilaa ja vastavuoroisen vuorovaikutuksen muodostuminen oli vaikeampaa. Tällöin asiakkaiden toimijuus helpommin suuntautui sairauden kieltäväksi, torjuvaksi tai itseään sairaudelta suojelevaksi. $(14,19)$ Useampi haastateltava itki kertoessaan kokemuksiaan ja kuvatessaan tapahtumaketjua, 
kun diagnoosi annettiin. Tieto sairaudesta oli ollut niin vaikea ottaa vastaan, että haastateltavat olisivat toivoneet itselleen helpompaa tilannetta tiedon saamisen hetkellä sekä välineitä tiedon käsittelyyn. Osa haastateltavista sai diagnoosin puhelimitse ja osa kasvotusten. Pelkästään diagnoosin antaminen kasvotusten ei itsessään luonut sosiaalista tilaa haastateltujen toimijuudelle. Suurin osa kasvotusten diagnoosin saanneista toivoi, että lääkäri olisi toiminut empaattisemmin ja ymmärtäväisemmin.

”- - lääkäri - - sanoi ensimmäistä kertaa, että se vois olla MS-tauti - - aloin - - itkemään - - lääkäri-- niin kauheen tyly -- miks itket - - sulla vois olla vaikka ALS - -”

"- - oon odottanut liian kauan - - vaivuin - shokkiin - - kun tajusin, että en saa - - lääkäristä enempää irti, hän vaan sano, että älä nyt hyppää jokeen - - voin tosi huonosti, minua ei olis saanut päästää pois huoneesta - -”

”- - Onhan se niin järkyttävä juttu, ettei sitä oikeestaan tajua. Mulla oli noin kuuden vuoden prosessi, että en puhunu siitä kenellekään - - olin silloin 19 eikä avuntarvitsija aina tai läheskään aina osaa olla aktiivinen tarvitsija. Olihan se sairaalalta aivan tajuttoman väärin - -"

Lähes kaikkien haastateltujen toimijuus sosiaali- ja terveyspalveluissa alkoi tilanteessa, jossa he olivat jääneet diagnoosin kanssa yksin, ilman ammatillista pitkäkestoista tukea sairauden käsittelyyn. Jotkut haastatelluista kyllä tapasivat psykologia, psykiatria tai sosiaalityöntekijää ensitiedon yhteydessä, mutta eivät halunneet tavata työntekijöitä uudelleen. Yleisesti haastatelluille ei ensitiedon yhteydessä annettu aluksi tarpeeksi tilaa voimakkaille tunteille ja vaikeudelle ottaa tietoa vastaan sekä sen jälkeen vahvasti tuettu ja ohjattu ammatillisen tuen piiriin.

Pitkäkestoisen ammatillisen tuen puute ensitiedon jälkeen johti siihen, ettei haastatelluilla aluksi ollut mahdollisuutta sosiaali- ja terveyspalvelujen sisällä olla omaan tilanteeseensa vaikuttavia toimijoita. He eivät voineet kuntoutujina alusta alkaen muodostaa toimintakäytäntöjä yhdessä ammattilaisten kanssa. (4, 19) Heillä ei ollut riittävästi tietoa erilaisista kuntoutusmuo- doista, eivätkä he voineet yhdessä ammattilaisten kanssa päättää kuntoutuksen ajankohtaa. Näiden haastateltujen toimijuutta muokkasi aluksi sosiaali- ja terveyspalvelujen ulkopuolinen sosiaalinen tuki.

\section{KUNTOUTUS OSANA SOSIAALI- JA TERVEYSPALVELU- JEN TOIMINTAKÄYTÄNTEITÄ}

Vaikka haastatellut pääosin olivat ulkopuolisia ammatilliseen apuun sairauden alussa, psykologin tai muun työntekijän pitkäkestoinen tuki tai MS-liiton kuntoutus oli kuitenkin löytynyt suurelle osalle haastatelluista, kun diagnoosista oli kulunut vuosia tai vähintään kuukausia. Samalla he olivat tulleet vahvemmin osaksi sosiaali- ja terveyspalveluja ja lääkinnällistä kuntoutusta, josta haastateltujen kokemukset olivat pääasiassa positiivisia. Kaikki haastatellut eivät kuitenkaan mieltäneet saamaansa tukea kuntoutukseksi, eivätkä halunneet ajatella itseään kuntoutujiksi. Tätä selittää osin haastateltavien suppea käsitys kuntoutuksesta. Haastatteluissa toistui pettymys lääkärien vaihtumiseen, mikä viivytti osaltaan kuntoutukseen pääsemistä. Suurimmalla osalla haastatelluista ei haastatteluhetkellä ollut pysyvää suhdetta lääkäriin, vaikka sairauden diagnosoinnista oli vuosia.

” - - enemmän tietoa ja lääkärin tukea - - vaikeeta tietenkin, että lääkäri vaihtuu joka ainut kerta - - lääkäreitä oli vaikea tavoittaa, saada puhelinaikaa tai edes lääkärin vastaanottoaikaa - - aina eri lääkäri ja alusta piti kertoa - - kohtasin - - aika tylyä kohtelua - - mun mielestä aika ammattitaidotontakin - - tarvis empatiakykyä - -”

" - - koko aika neurologi vaihtui - - epikriiseissä - - oli vähän jopa virheellistä tietoa - - sen oli kirjoittanut niin moni eri neurologi, - - onneksi sairaanhoitaja oli koko aika sama - -”

Kuntoutuksen puutteellinen suunnitteleminen puolestaan selittää haastateltujen vaikeutta ymmärtää kuntoutusprosessiaan kokonaisuutena. Suurin osa haastateltavista ei tuonut millään tavalla esiin kuntoutussuunnitelmaa, eikä kukaan maininnut suunnitelleensa omaa kuntoutustaan yhdessä oman lääkärin tai moniammatillisen tiimin kanssa. Ne haastatellut, jotka tiesivät oi- 
keutensa kuntoutussuunnitelmaan ja pitivät sitä tarpeellisena, kertoivat, etteivät ole suunnitelmaa omasta halustaan huolimatta saaneet.

"- - kuntoutussuunnitelma, joka ilmeisesti lakisääteisesti kaikille pitäis tehdä, olen saanut - - aika suoraan sanottuna kuvan, et olen liian terve sellaiseen suunnitelmaan - - kuntoutuksesta vois olla hyötyä, ainakin kartottaa - - olis - - ennalta ehkäisevää - - ellei oo tosi pahasti - - sitä ennen ei tehdä mitään ennakoivaa - -”

”- - tiedän, että mulle pitäisi tehdä kuntoutussuunnitelma - - fiksuahan se olis - - en usko, että tehdään, ellen pyydä, en usko - - että tehdään välttämättä silloinkaan - -”

Haastateltujen puuttuvat kuntoutussuunnitelmat tai tietämättömyys mahdollisen kuntoutussuunnitelman olemassaolosta kuvastivat ammattilaisten ja haastateltujen yhteistyön vähäisyyttä sekä haastateltujen mahdollisuuksia muokata sosiaali- ja terveyspalvelujen sosiaalisia toimintakäytäntöjä (vrt. (19)). Järvikoski ym. (32) käyttävät käsitettä jaettu toimijuus (shared agency), jossa toimijat tekevät yhteiseen suunnitteluun, sitoutumiseen, vastuuseen ja tukeen perustuvaa yhteistyötä. Kun sosiaali- ja terveydenhuollon asiakkaiden ja ammattilaisten yhteistyö perustuu jaettuun toimijuuteen, vastuuta kuntoutuksen oikea-aikaisuudesta tai sisällöstä päättämisestä ei ole siirretty kuntoutujalle. Sen sijaan ammattilaisten ja kuntoutujan vuorovaikutuksessa on tilaa vaikeille tunteille ja epävarmuuksille, jotka voidaan huomioida kuntoutuksen yhteisessä suunnittelussa.

\section{OMAN SAIRAUDEN HYVÄKSYMINEN JA TOIMIJUUS SOSIAALI- JA TERVEYSPALVELUISSA}

Tutkimusaineisto kuvaa haastateltavien oman sairautensa hyväksymistä. Haastateltujen suhde omaan sairauteensa muuttui elämänkulun ja hyväksymisprosessin etenemisen myötä. Kun suhde sairauteen muuttui, usein myös ajatukset kuntoutuksesta muuttuivat. Tämä tuli paremmin esiin haastatelluilla, joilla oli diagnoosin saamisesta vähintään neljä vuotta. Koska useilla haastatelluista diagnosointitilanne oli antanut vaikean alun omien tunteiden käsittelylle, he eivät pystyneet suhtautumaan omiin osaamisiinsa, haluami- siinsa ja voimisiinsa tasapainoisesti (21). Heidän suhteensa omaan sairauteensa oli tunnepitoinen usein kuukausien tai vuosien ajan.

Toimijuuden muutoksissa korostui sosiaalinen tuki, kun ammatillinen tuki jäi liian vähäiseksi. Paju (22) esittää toimijuuden tietynlaisen toiminnan mahdollisuutena edellyttäen riippuvuutta ja sidoksia inhimillisiin ja ei-inhimillisiin toisiin. Haastateltujen toimijuutta kannattelivat riippuvuudet ja sidokset perheeseen, läheisiin, työhön, opiskeluun, harrastuksiin, lemmikkeihin ja päivittäisiin rutiineihin. Toisilta ihmisiltä saatu sosiaalinen tuki, mutta myös harrastusten ja kiinnostuksen kohteiden tuomat sidokset vahvistivat voimisen, kykenemisen, osaamisen ja haluamisen modaliteetteja. Näin vankistui toimijuuden modaliteeteista muodostuva kokonaistoimijuus. Vaikka ammatillinen tuki oli vähäistä, saattoi kokonaistoimijuudesta kehittyä vahvaa, jos haastatellulla oli paljon vahvoja kiinnikkeitä elämään (21).

Vaikka sairauden oireet eivät yleensä pahenemisvaiheiden välillä näkyneet ulkopuolisille, ja haastatellut jatkoivat työtään tai opiskeluaan, vähintään tietoisuuden tasolla MS-tauti vaikutti jokaisen haastatellun toimijuuteen. Kaikilla haastatelluista oli kokemuksia fyysisten kykyjen tilapäisestä huononemisesta. Useammalla haastateltavalla jokin fyysinen oire oli jäänyt pysyväksi tai herkästi uusiutuvaksi. Muutama haastateltu oli menettänyt jonkin fyysisen kyvyn kokonaan. Nämä kokemukset loivat epävarmuutta haastateltujen omien tavoitteiden ja päämäärien saavuttamiselle ja niille mahdollisuuksille, jotka olivat tavoitettavissa. Fyysisistä kyvyistä luopuminen oli pakottava alku diagnoosin tuomien voimakkaiden tunteiden käsittelylle. Suurin osa haastatelluista kertoi, kuinka sairaus oli pysäyttänyt miettimään, mitä elämältä todella halusi. Tämä oli alku sairauden käsittelylle, joka pidemmällä aikavälillä vahvisti sairastuneiden psyykkisiä kykyjä ja sitä kautta heidän kokonaistoimijuuttaan (21).

"- - iloinen, sain kokea sen, että - - kun mun maailma kaatu, kaikki muu ei kaadu sen kanssa - -"

”- - elämänarvot laittanut kokonaan uuteen järjestykseen sen diagnoosin jälkeen - - on oppinut arvostamaan eri asioita - -" 


\begin{tabular}{c|c|c} 
& \multicolumn{2}{|c}{ Suhde sairauteen } \\
\hline Toimijuus & Hyväksyminen & Kieltäminen \\
\hline Aktiivinen & $\begin{array}{c}\text { Tiedostava, omista eduista } \\
\text { taisteleva toimijuus }\end{array}$ & $\begin{array}{c}\text { Sairaudelta itseään suojeleva } \\
\text { toimijuus }\end{array}$ \\
\hline Passiivinen & $\begin{array}{c}\text { Sairauden suhteen odottava } \\
\text { toimijums }\end{array}$ & $\begin{array}{c}\text { Sairauden kieltävä ja torjuva } \\
\text { toimijuus }\end{array}$
\end{tabular}

Kuvio 1. Toimijuus ja suhde sairauteen

Luokittelen aineiston perusteella neljä toimijuuden tyyppiä, jotka kuvastavat haastateltuja suhteessa omaan sairauteensa, ja heidän tapaansa ymmärtää oma roolinsa sairauden, kuntoutuksen ja muun elämän yhteensovittamisessa haastatteluhetkellä. Toimijuuden tyypit on tiivistetty seuraavassa kuviossa. Vaaka-akseli kuvaa suhdetta omaan sairauteen ja pystyakseli toimijuuden luonnetta suhteessa omaan elämään, sosiaali- ja terveyspalveluihin sekä kuntoutukseen. Toimijuus ei ole pysyvää ja samoin toimijuuden tyyppi voi muuttua.

Parhaimmillaan toimijuus muodostui sairauden suhteen hyväksyväksi, sosiaali- ja terveyspalvelujen toimintakäytännöt tiedostavaksi ja päämäärätietoiseksi omista eduistaan taistelevaksi. Tällaiset haastatellut edistivät aktiivisesti omaa tilannettaan sosiaali- ja terveyspalveluissa ja halusivat tai vaativat kuntoutusta. Toisaalta tiedostavuus ja toimintakäytäntöjen taustalla olevien kirjoittamattomien sääntöjen ymmärtäminen aiheuttivat turhautumista ja vihan tunteita, kun asianmukaisen hoidon ja kuntoutuksen esteenä olivat riittämättömät resurssit (vrt. $(13,18))$.

”- - haluan asian viedä loppuun ja selvittää - - joku muu - - tilanteessa, et on masentunut tai - - voimat vähissä - - voi apu jäädä hakemattakin - -"

"- - jotkut lääkärit ei oo tajunnu, että ihmissuhde on se juttu, vaan niin kun näkee tän kliinisenä - - mullakin on - - oikeus valita kenen kanssa työskentelen - - en haluu olla - - numero muiden joukossa, ihminen täytyy kohdata - - pitää arvostaa ja kunnioittaa - -”
Kaikkien elämäntilanne ei kuitenkaan mahdollistanut sairauden käsittelyn aloittamista. Joillakin haastatelluista toimijuus saattoi muodostua sairauden kieltäväksi tai torjuvaksi useiden vuosien ajan. Näiden haastateltujen toimijuutta saattoi varjostaa masennus, eivätkä voimavarat tuntuneet riittävän tavalliseen arkeen. Omalla vuorovaikutuksellaan he karttoivat kuntoutusta, tai kuntoutus ei auttanut heitä kohtaamaan itseään. He halusivat tiukasti pitää kiinni ajatuksesta, ettei heillä ole sairautta, mutta samalla rajasivat itseään tarvitsemansa avun ulkopuolelle. (Vrt. (21).) He saattoivat salailla sairauttaan jopa läheisiltään. Joidenkin haastateltujen kohdalla tiedostavat ammattilaiset pyrkivät saamaan haastateltuja tietoisiksi omista toimijuuksistaan ja ohjasivat heitä hoidon ja kuntoutuksen piiriin.

"- - koetan olla antamatta MS:n näkyä elämässä - - koetan aina muilta sen piilottaa, ettei kukaan sais tietää - -"

”- - En tiedä kuka lääkäri siellä sitten on, mutta ne koettaa taas puhua mua aloittamaan lääkettä - - niin kauan kun mulla ei ole lääkettä, mitä jatkuvasti pistelen, niin ei mua kauheesti mikään vaivaa - -"

Sairauden kieltäjillä toimijuus muilla elämänalueilla saattoi olla kuitenkin aktiivista ja tavoitteellista, vaikka oireina sairaus oli läsnä. Nämä haastatellut olivat kääntäneet tulevaisuuden epävarmuuden kiireeksi elää ja toimia omien unelmien eteen heti, jolloin he saattoivat elää entistä intensiivisemmin omaa arkea. Tällöin toimijuus oli itsensä suojelemista sairaudelta. Nämä haastatellut eivät pysähtyneet pohtimaan sairautta, ja 
sen tuomia elämänmuutoksia, vaikka tieto sairaudesta oli ollut selvä jo vuosia. Sen sijaan he toteuttivat muiden elämänalueiden tavoitteitaan ja pyrkivät aktiivisesti unohtamaan sairautensa. $\mathrm{He}$ olivat saattaneet osallistua kuntoutukseen, mutta se ei ollut auttanut heitä kohtaamaan sairautta.

Taustalla oli myös tietämättömyyttä ja epäluuloisuutta kuntoutusta kohtaan. Ammattilaisten ja haasteltujen vuorovaikutus ensitiedon yhteydessä tai pian sen jälkeen ei ollut sisältänyt syvällistä ajatustenvaihtoa kuntoutuksesta tai kuntoutuksen tehtävän yhteistä pohdintaa ilmaisullisen tietoisuuden tasolla (19). Tällöin haastateltu ei tiedostanut omaa toimijuuttaan suhteessa kuntoutukseen. Hän oli jäänyt yksin sopeutumaan sairauteensa, kohtaamaan omia ja yhteiskunnassa vallitsevia sairaus- ja vammakäsityksiä sekä kehittämään omia selviytymisstrategioita ja -keinoja (33).

"- - huomaan mun jaksaminen, mun keskittymiskyky - - en tiedä, onko se sairautta - - en oo nähnyt tarpeelliseksi käydä MS-yhdistyksen - - hapeningeja - - oon joko eläkkeellä tai osatyökyvttömyyseläkkeellä - - silloin rupean kuntouttamaan itseäni - - tällä hetkellä en näe aihetta - - näen kuntotuksen tarpeelliseksi, kun en osaa kävellä - - toivon mukaan ei koskaan - -"

"- - MS-tauti, niin sitten oot sairas. Sairaushan on vaan olotila - - eihän se tee sua sairaaks sinsänsä - - mulla on tämmönen sairaus, mutta siitä huolimatta voin tehdä kaikkea, mitä haluan - -”

Samanlaisia piirteitä kuin sairaudelta itseänsä suojelevassa toimijuudessa oli myös sairauden suhteen odottavassa toimijuudessa. Tähän toimijuuteen liittyi sairauden käsittelyprosessin keskeneräisyys ja usein melko tuore diagnoosi, jolloin toimijuus sosiaali- ja terveyspalveluissa oli vasta muodostumassa ja kuntoutus sisältöineen oli vielä vierasta. Vaikka haastatellut kertoivat hyväksyneensä sairautensa ja suhtautuivat sairauteen positiivisesti, toimijuus oli odottavaa. He olisivat tarvinneet ammattilaisten keskustelullista tukea ja kuntoutustietoutta lähteäkseen kuntoutukseen. Nämä haastatellut eivät olleet valmiita kohtaamaan toisia MS-tautia sairastavia tai he eivät kokeneet kuntoutusta vielä ajankohtaiseksi ja itseään kuntoutettaviksi. He eivät aktiivisesti ajaneet omaa asiaansa sosiaali- ja terveyspalveluissa, jossa heillä oli ollut vasta vähän vuorovaikutustilanteita. Heidän toimijuutensa muilla elämänalueilla oli aktiivista, mutta he eivät paenneet sairauttaan. Sairaudesta puhuminen oli kuitenkin tunnepitoista, jolloin sopeutumisvalmennus olisi saattanut helpottaa sairauden käsittelyssä ja suhtautumisessa kuntoutukseen. Odottavaa toimijuutta selitti myös MS-taudin aaltomainen luonne. Sairaus ei ollut vielä vaatinut paljon käsittelemistä, mikäli haastatelluilla oli ollut vain muutamia pahenemisvaiheita, joista he olivat palautuneet hyvin. Tällöin ei kuntoutus usein tuntunut tarpeelliselta.

\section{JOHTOPÄÄTÖKSET JA POHDINTA}

Artikkelissa on kuvattu 14 MS-tautiin sairastuneen nuoren aikuisen toimijuutta diagnoosin saamisen jälkeen sosiaali- ja terveyspalveluissa, kuntoutuksessa tai sen ulkopuolella. Suurimmalla osalla haastatelluista voimakkaat tunteet ja sairauden käsittelyn keskeneräisyys estivät rationaalisen, päämäärätietoisesti omaa asiaa ajavan ja reflektoivan toimijuuden sosiaali- ja terveyspalveluissa (13). Tiedostavan ja omista eduista taistelevan toimijuuden sijaan haastateltujen toimijuus oli useammin sairaudelta itseltään suojelevaa, odottavaa tai sairauden kieltävää torjuvaa toimijuutta. Haastatteluaineisto kuvaa myös suomalaisen kuntoutuksen kentän ongelmallisuutta. Suomalainen kuntoutusjärjestelmä ei ole yksiselitteinen. Kuntoutusta ohjaavat useat eri lait ja kuntoutusta järjestävät useat eri organisaatiot. Vaikka eri järjestäjätahojen kuntoutusvastuu on integroitu osaksi yleisiä palveluja ja sosiaaliturvaa, kuntoutusjärjestelmien yhteensovittaminen on vaikeaa kuntoutuksen ammattilaisille ja erityisesti asiakkaille. (34)

Haastateltujen tehtäväksi muodostui helposti omien oikeuksien selvittäminen sosiaali- ja terveyspalveluissa sekä oman asian ajaminen kuntoutukseen pääsemiseksi. Tähän tutkimukseen haastatellut olivat vapaaehtoisia, pääosin hyvin koulutettuja ja MS-liiton jäseniä. Kuitenkin suurimmalla osalla haastatelluista heidän oma sairauden kieltävä ja torjuva toimijuus, itseä suo- 
jeleva toimijuus tai odottava toimijuus osaltaan esti aktiivista omien oikeuksiensa ajamista ja kuntoutuksen mahdollisimman varhaista aloittamista. Kuntoutuksen vanha ongelma onkin, että kuntoutustarve todetaan liian myöhään (35). Halosen ym. (36) tekemä, vuonna 2002 Kelan kuntoutukseen MS-taudin perusteella osallistuneita koskenut tutkimus osoitti, että MS-tautia sairastavien kuntoutus pitäisi aloittaa mahdollisimman pian diagnoosin jälkeen sairauden aaltomaisessa vaiheessa. Tällöin kuntoutujilla olisi mahdollisuus pahenemisvaiheiden välillä hyödyntää kuntoutustoimenpiteitä. Kuitenkin Kelan kuntoutuksessa olevat MS-tautia sairastavat olivat yleisimmin 45-65-vuotiaita työkyvyttömiä henkilöitä, jotka täyttivät vaikeavammaisuuden kriteerit.

Haastateltujen vähäinen osallistuminen sosiaali- ja terveyspalvelujen toimintakäytäntöihin vaikeutti aktiivisen ja oman sairauden hyväksyvän toimijuuden muodostamista. Haastateltujen kuntoutukseen lähtemistä olisi voinut helpottaa laaja-alaisempi ja vastavuoroinen keskustelu kuntoutuksen sisällöistä, oikea-aikaisuudesta ja tarpeellisuudesta yhdessä ammattilaisten kanssa, heti kun diagnoosi oli tuore. Ammattilaisten antama asiantunteva tieto parantaisi kuntoutustietoisuutta ja todennäköisesti helpottaisi itsensä mieltämistä kuntoutujaksi.

Samoin haastatellut olisivat voineet päästä paremmin osaksi toimintakäytäntöinä tapahtuvaa vuorovaikutusta, jos heidät olisi heti diagnoosin jälkeen selkeämmin nähty kuntoutuksen valtaistavan paradigman mukaan sosiaali- ja terveyspalvelujen toimijoina, ja heitä olisi autettu mukaan kuntoutuksen suunnitteluun (vrt. (4, 32)). Ne haastateltavat, joilla sairauden myöhempinä vuosina oli pitkäkestoinen hoitosuhde lääkärin tai muun ammattilaisen kanssa pitivät suhteita erittäin hyvinä. Hoitosuhteen saaminen vaan vaati MS-tautiin sairastuneilta omaa aktiivisuutta.

MS-tauti diagnosoidaan yleisimmin nuorilla 20-40-vuotiailla aikuisilla. Heidän kuntoutuksensa oikea-aikaisuuden huomioiminen ja lainmukainen suunnitteleminen ovat kansantalou- dellisesti kannattavia toimia. Kuntoutuksessa tulisi huomioida myös psykologinen varhaiskuntoutus sairauden hyväksymisen käsittelyyn, jotta MS-tautiin sairastuneiden olisi helpompi hyväksyä ajatus itsestä kuntoutujana ja kuntoutus voitaisiin aloittaa silloin, kun se on tutkitusti kannattavinta (36). MS-tautiin sairastuneiden kuntoutuksen aikaistamista tukee myös vuoden 2016 alusta Kelan vaikeavammaisten lääkinnällisen kuntoutuksen muuttuminen vaativaksi lääkinnälliseksi kuntoutukseksi. Siinä kuntoutukseen pääseminen perustuu todettuun tarpeeseen, eikä enää tiukasti saatuihin tukiin. (37)

Tämän tutkimuksen tarkoitus on hoito- ja kuntoutuskäytäntöjen kehittäminen nuorena MStautiin sairastuneiden kokemusten avulla. Tutkimukseni on osoittanut, että pitkäaikaissairaiden hoito- ja kuntoutuskäytäntöjen käsitteellistäminen ja mallintaminen on yksi keino kehitettäessä kuntoutukseen ohjaamista ja sisältöjä. Käsitteellistäminen ja mallintaminen auttaa sosiaali- ja terveysalan ammattilaisia ymmärtämään hoitokuntoutuskäytäntöjä ilmaisullisen tietoisuuden tasolla (vrt. (19)), jolloin he tiedostavat paremmin jokapäiväiset toimintonsa työssään, voivat helpommin vaikuttaa omaan toimintaansa ja näin pystyvät huomioimaan enemmän asiakkaita inhimillisine ominaisuuksineen. Myös luokittelemani neljä MS-tautiin sairastuneen toimijuuden tyyppiä voivat yleisemmin auttaa ammattilaisia ymmärtämään pitkäaikaissairaiden ihmisten suhdetta omaan sairauteensa ja heidän toimijuuttaan suhteessa kuntoutukseen, kun diagnoosi on vielä melko tuore. (Vrt. (27).) Jatkossa hoito- kuntoutuskäytäntöjen kehittämisen kannalta tärkeää olisi tutkia moniammatillisen yhteistyön mahdollisuuksia ja voimavaroja diagnosoimattomien vakavien oireiden seurannassa ja tulkitsemisessa.

\section{KIITOKSET:}

Kiitän Suomen MS-säätiötä, jonka myöntämä apuraha mahdollisti artikkelin kirjoittamisen. 
Clinical and rehabilitation practices are an important part of the changing social and healthcare services. The purpose of this article is to introduce perspectives of young MS-patients on the clinical and rehabilitation practices that they have encountered, so that the practices could be developed. The data consists of the interviews of 14 working MS-patients aged between 26 and 33. The data has been analysed using theory-driven content analysis, where reasoning has been guided by Giddens' structuration theory and Jyrkämä's theoretical methodological framework of the modalities of agency. The study concerns the prevailing practices of the social and healthcare services and the agency of the MS-patients in relation to their own disorder and to rehabilitation. Based on the data, the agency of MS-patients in social and healthcare services was guided by the attitude of the patients towards their own disorder and by their interaction with professionals realized as prevailing practices. The MS diagnosis was difficult to receive. The manner of disclosing the diagnosis and the knowledge guiding the prevailing practices of the professionals were related to the chances of the interviewees to accept their own disorder and to seek rehabilitation. The lack of support from professionals when receiving the diagnosis left the interviewees alone to process the information on their disorder and directed the nature of their agency to be denying and escaping the disorder, protecting themselves from the disorder or waiting with respect to the disorder. For the agency of the interviewees to be conscious of their power and acting in their own interests in social and healthcare services, the interviewees had to process the effect of the disorder on their life holistically and they had to be conscious of their own agency in interaction in social and healthcare services. The study concludes that the low participation of the interviewees to the interaction realized as prevailing practices in social and healthcare services hindered forming an active agency accepting one's own disorder. Seeking rehabilitation may have been complicated by the complexity of the Finnish rehabilitation system and deficiencies in planning the rehabilitation. The interviewees might have benefited from early psychological rehabilitation. Conceptualizing and modelling the clinical and rehabilitation practices for chronic patients is a means to develop guiding to and the content of rehabilitation and to help the patient in the process of accepting the disorder.

Keywords: agency, rehabilitation, multiple sclerosis, social and healthcare services

Saapunut 15.11.2017

Hyväksytty 06.04.2018

\section{LÄHTEET}

(1) Krökki O. Multiple sclerosis in Northern Finland: epidemiological characteristics and comorbidities. Oulu: Oulun yliopisto; 2016.

(2) Pirttilä T, Reunanen M, Ruutiainen J. MS-taudin oireet, taudinkuva ja toteaminen. Kirjassa: Elovaara I, Pirttilä T, Fräkkilä M, Hietaharju A. (toim.) Kliininen neuroimmunologia. Helsinki: Yliopistopaino; 2006. 110-124.

(3) Koukkari M. Kuntoutujien käsityksiä kuntoutuksesta ja kuntoutumisesta. Kirjassa: Järvikoski A, Lindh J, Suikkanen A. (toim.) Kuntoutus muutoksessa. Rovaniemi: Lapin yliopistokustannus; 2011. 220-226.

(4) Karjalainen V. Yksilöllistymiskehitys muuttaa kuntoutusta - mutta miten? Kirjassa: Karjalainen V, Vilkkumaa I. (toim.) Kuntoutus kanssamme: ihmisen toimijuuden tukeminen. Helsinki: Stakes; 2004. 11-25.
(5) Honkasalo M-L. Reikä sydämessä: sairaus pohjoiskarjalaisessa maisemassa. Tampere: Vastapaino; 2008.

(6) Greener I. Expert Patients and Human Agency: Long-term Conditions and Giddens' Structuration Theory. Soc Theory Health. 2008;6(4):273-290. doi: 10.1057/sth.2008.11

(7) Lämsä R. Potilaskertomus: etnografia potiluudesta sairaalaosaston käytännöissä. Helsinki: Terveyden ja hyvinvoinnin laitos; 2013.

(8) Koivula R. Muistisairaan ihmisen omaisena terveyskeskuksen pitkäaikaisosastolla: tutkimus toimijuudesta. Helsinki: Terveyden ja hyvinvoinnin laitos; 2013.

(9) Reunanen MAT. Toimijuus kuntoutuskokemusten kerronnassa ja fysioterapian kohtaamisissa. Rovaniemi: Lapin yliopisto; 2017. 
(10) Hoppe S. "Getting sick has been good to me, not bad": understanding the experience of growth in face of adversity. Medische Antropologie. 2009;21(2):277-296

(11) Thapar N, Bhardwaj SM, Bhardwaj CA. Multiple Sclerosis in its Context: Individual Narratives. Disability Stud Q. 2001;21(4):29-41

(12) Jyrkämä J. Ikäihmiset, teknologia ja toimijuus. Kirjassa: Leikas J. (toim.) Ikäteknologia. Helsinki: Vanhustyön keskusliitto; 2014. 59-69.

(13) Giddens A. The constitution of society: outline of the theory of structuration. Cambridge: Polity; 1984.

(14) Jyrkämä J. Sosiaalinen vanheneminen, Anthony Giddens ja toimintakäytännöt. Gerontologia. 1995;9(4):241-251

(15) Heiskala R. Toiminta, tapa ja rakenne: kohti konstruktionistista synteesiä yhteiskuntateoriassa. Helsinki: Gaudeamus; 2000.

(16) Giddens A. Social theory and modern sociology. Cambridge: Polity Press; 1988.

(17) Giddens A. Central problems in social theory: action, structure and contradiction in social analysis. London: Macmillan Press; 1979.

(18) Ilmonen K. Anthony Giddensin rakenteistumisteoria ja sen kritiikki. Kirjassa: Heiskala R. (toim.) Sosiologisen teorian nykysuuntauksia. Helsinki: Gaudeamus; 1994. 316-347.

(19) Giddens A. Yhteiskuntateorian keskeisiä ongelmia: toiminnan, rakenteen ja ristiriidan käsitteet yhteiskunta-analyysissä. Helsinki: Otava; 1984.

(20) Hoggett P. Agency, Rationality and Social Policy. J Soc Policy. 2001;30(1):37-56

(21) Jyrkämä J. Toimijuus, ikääntyminen ja arkielämä: hahmottelua teoreettismetodologiseksi viitekehykseksi. Gerontologia. 2008;22(4):190-203

(22) Paju E. Lasten arjen ainekset: etnografinen tutkimus materiaalisuudesta, ruumiillisuudesta ja toimijuudesta päiväkodissa. Helsinki: Tutkijaliitto; 2013.

(23) Kylmä J, Juvakka T. Laadullinen terveystutkimus. Helsinki: Edita; 2007.

(24) Pohjola A. Tutkijan eettiset sitoumukset. Kirjassa: Pohjola A. (toim.) Eettisesti kestävä sosiaalitutkimus. Lapin yliopiston yhteiskuntatieteellisiä julkaisuja C, Työpapereita 47. Rovaniemi: Lapin yliopisto; 2003. 53-67.

(25) Kuula A, Tiitinen S. Eettiset kysymykset ja haastattelujen jatkokäyttö. Kirjassa: Ruusuvuori J, Nikander P, Hyvärinen M. (toim.)
Haastattelun analyysi. Tampere: Vastapaino; 2010. 446-459.

(26) Eskola J, Suoranta J. Johdatus laadulliseen tutkimukseen. Tampere: Vastapaino; 1998.

(27) Ruusuvuori J, Nikander P, Hyvärinen M. Haastattelun analyysin vaiheet. Kirjassa: Ruusuvuori J, Nikander P, Hyvärinen M. (toim.) Haastattelun analyysi. Tampere: Vastapaino; 2010. 9-36.

(28) Tuomi J, Sarajärvi A. Laadullinen tutkimus ja sisällönanalyysi. Helsinki: Tammi; 2013.

(29) Graneheim UH, Lundman B. Qualitative content analysis in nursing research: concepts, procedures and measures to achieve trustworthiness. Nurse Educ Today. 2004;24(2):105-112. doi: 10.1016/j.nedt.2003.10.001

(30) Krippendorff K. Content analysis: an introduction to its methodology. Thousand Oaks: Sage; 2004.

(31) Ruusuvuori J, Tiittula L. Tutkimushaastattelu ja vuorovaikutus. Kirjassa: Tiittula L, Ruusuvuori J. (toim.) Haastattelu: tutkimus, tilanteet ja vuorovaikutus. Tampere: Vastapaino; 2005. 22-56.

(32) Järvikoski A, Martin M, Autti-Rämö I, ym. Shared agency and collaboration between the family and professionals in medical rehabilitation of children with severe disabilities. Int J Rehab Res. 2013;36(1):30-37. doi: 10.1097/MRR.0b013e32835692d3

(33) Smart J. Disability, Society, and the Individual. Gaithersburg: Aspen; 2001.

(34) Vammaispalvelujen käsikirja: Terveyden ja hyvinvoinnin laitos; Luettu 30.9.2017. http:// www.thl.fi/fi/web/vammaispalvelujen-kasikirja.

(35) Järvikoski A, Härkäpää K. Kuntoutuskäsityksen muutos ja asiakkuuden muotoutuminen.

Kirjassa: Rissanen P, Kallanranta T, Suikkanen A. (toim.) Kuntoutus. Helsinki: Duodecim; 2008. 51-61.

(36) Halonen J-P, Aaltonen T, Lind J, ym. Kelan järjestämä kuntoutus MS-tautia sairastavalle. Kuntoutus. 2012;35(1):21-28

(37) Laki kansaneläkelaitoksen kuntoutusetuuksista ja kuntoutusrahaetuuksista annetun lain muuttamisesta 20.2.2015/145.

Suvi-MaAria Tepora-Niemi

YTM, tohtorikoulutettava, apurahatutkija

Helsingin yliopisto

Sosiaalitieteiden tohtoriohjelma 